\title{
ÉVOLUTION DE L'AZOTE \\ AU COURS DU TRAITEMENT BIOLOGIQUE DU LISIER DE PORC
}

\author{
J.-C. BOURDELOT \\ Société Degremont, \\ $B, P .46,92$ Suresnes
}

\begin{abstract}
RÉSUMÉ
Les études entreprises sur le traitement biologique du lisier de porc, tant en laboratoire que sur un pilote semi-industriel nous ont montré que :

- Ia nitritation serait l'œuvre essentiellement d'autotrophes,

- la nitratation, par contre, serait l'œuvre d'hétérotrophes,

- l'élimination de NTK et de l'azote est satisfaisante,

- mais que dans la chaîne de nitrification nous étions arrêtés au stade nitrite; aucune réponse satisfaisante n'a pu être apportée à ce phénomène.
\end{abstract}

\section{SUMMARY}

EVOLUTION OF NITROGEN DURING BIOLOGICAL, TREATMENT OF SWINE WASTE

Studies about biological treatment of swine waste, as well in a laboratory plant as in a halfscale industrial plant, have shown that :

- nitritation mainly depends on autotrophic bacteria,

- nitratation, on the other hand, is mainly due to heterotrophic bacteria.

- NTK and nitrogen removal is satisfactory,

- but in the nitrification chain it has not been possible to overpass the nitrite step. No answer has been given to this phenomenon.

Rę̧u pour publication en mars 1973. 